\title{
Analysis of the Effect of Strategic Direction on Performance of Motor Vehicle Assembly Firms in Nairobi City County, Kenya
}

\author{
Shem Maina Kungu ${ }^{1 *}$, Dr. Julius Kahuthia ${ }^{1}$, Dr. Godfrey Kinyua ${ }^{2}$ \\ ${ }^{I}$ Faculty of Business, Computer Science and Communication Studies St. Paul's University, Nairobi, Kenya \\ ${ }^{2}$ School of Business, Kenyatta University, Nairobi, Kenya
}

*Corresponding Author: Shem Maina Kungu, Faculty of Business, Computer Science and Communication Studies St. Paul's University, Nairobi, Kenya

\begin{abstract}
The vehicle Assembly industry which is a subsector of the automotive sector in Kenya has faced significant challenges in the last 15 years. Challenges faced by the subsector include low research and development, low skill levels by employees, lack of supportive standards and regulations and lack of capacity building to support the automotive industry more so the vehicle assembly subsector. In the Kenyan market $80 \%$ of motor vehicles, are second hand motor vehicles and this raises questions about the performance of vehicle assemblers in Kenya. The general objective of this study was to investigate the effects of strategic direction and performance of motor vehicle assembly firms in Nairobi City County, Kenya. The Upper Echelon Theory provided anchorage to the study. The study adopted a descriptive research design targeting 46 members of senior management, 112 members of middle level management and 156 members of lower level management hence a total of 314 respondents. Stratified random sampling technique was adopted and 157 respondents were identified for the study. Primary data was used as collected through the questionnaire. Data was analyzed using descriptive and inferential statistics including simple regression analysis. Study findings were presented in tables, pie charts and bar graphs. The findings of the study indicated strategic direction had positive and significant effect on the firm performance of motor vehicle assembly firms. The study concludes that strategic direction has a positive and significant effect on firm performance. The study recommends that senior managers of all motor vehicle assembly firms in Nairobi City County, Kenya should adopt strategic direction practices by focusing on the mission and vision statements of their organizations.
\end{abstract}

Keywords: Strategic Direction, Firm Performance

\section{INTRODUCTION}

The nature of business environment has become dynamic posing an increasing level of uncertainty and a challenge to the performance of different firms (Richard, Devinney, Yip \& Johnson, 2009). The construct of strategic direction has been seen as a dominant issue that informs the base of the performance of many firms in the globe. Strategic direction is widely believed to be one of the key drivers of the performance of many firms. According to Shariff (2016) firm performance is very crucial issue that is used to measure the organization success.

On overall, there has been an improvement in the automotive industry in the past decade. This improvement has particularly been seen in the United States especially with the recovery of sales and profits after some periods of economic crises. The other areas with marked improvement are China that has been characterized by strong growth (McKinsey, 2020). It is expected that this trend in improvement in the automotive industry would continue like that as per the McKinsey and company (2020) with an expected rise by about 50\% around the globe. The key emerging markets that would generate more new profits will include Southern Korea, Japan, Europe and the USA. For instance, a total of about 112 million jobs in Europe are as a result of the automotive industry and this figure stands at around 8 million in USA and above 5 million in Japan (McKinsey, 2020).

In the sub-Saharan region, there is low level of industrialization with less than $10 \%$ of the Gross Domestic Product (GDP) being explained by the manufacturing sector (African Development Bank, 2019). Away from South Africa including some of the states in Northern part of Africa, there are even no evidence to support production of motor vehicles (Black \& McLennan, 2016). There is some motor vehicle assembly in some of the areas in Northern part of Africa with one largest plant in Morocco 
whose accumulated investment totals up to €1billion (Black \& McLennan, 2016). According to Schiller (2018), about $80 \%$ of the overall turnover in Kenya, Nigeria and Ethiopia was attributed to the imported second hand vehicles. This signifies the growing attractiveness of people on second hand vehicles.

According to information from the Kenya National Bureau of Standards (KNBS), about $80 \%$ of the cars imported in Kenya are the used cars on a yearly basis. With such high numbers of second-hand cars, the market for locally assembled vehicles is undermined, constraining its growth. However, compared to other countries, vehicle assembly in Kenya still has a long way to go, to compete at global levels. Drawing comparisons with other nations that have heavily invested in local vehicle assembly, the growth opportunities are immense and the return on investments is unquestionable. According to the Ministry of Trade and Industrialization, the future of automotive industry was thrown out of balance in the 1990s as the liberalization era ushered in cheap used car imports. From this era up to the present days, the motor assembly industry has been facing challenges in order to remain viable and this has adversely affected the component industry with most shops having been closed down. Kenya has vehicle assembly lines with a combined capacity of producing 34,000 units a year (KAM, 2018). According to Kavashe (2018), there should more focus to drive the growth of vehicle assembly in Kenya which is weak in performance and is not performing while keeping up with developments in the region and globally.

The existing body of empirical literature present diverse measures of organization performance. For instance, such measures as return on asset, return on investment, marketshare, customer satisfaction, employees' satisfaction,competitive position and success rate in launching newproduct have been used as indicators of firm performance (Fauzul\& Tanaka,2010; Mirugi\&Kinyua, 2018). Similarly, customer loyalty, market share, brand image, efficiency, customer retention, profitability have also been used to operationalize firm performance (Kimaru\&Kinyua, 2018; Mbugua\&Kinyua, 2020). In the motor vehicle assembling sub-sector, Muthoni and Kinyua (2020) operationalized organization performance as customer retention, turn-around time, rate of defect, lead time and employee retention. In this study, performance of Motor Vehicle Assembling Firms was construed as customer satisfaction, customer retention, turn-around time, rate of defect, lead time and employee retention.

\section{Statement of the Problem}

The vehicle assembly industry which is a subsector of the automotive sector in Kenya has faced significant challenges in the last 15 years. Challenges faced by the subsector according to KAM (2018) include low research and development, low skill levels by employees, lack of supportive standards and regulations and lack of capacity building to support the automotive industry more so the vehicle assembly subsector. In the Kenyan market, $80 \%$ of motor vehicles are second hand and this raises questions about the performance of vehicle assemblers in Kenya. Strategic direction is vital for performance and success of firms (Nthini, 2013). This is because strategic direction essentially helps in charting the path which a firm would take either into profitability or loss making. Globally, various scholars have demonstrated that strategic direction has positive effect on firm performance (DuBrin, 2012; Gallos\& Heifetz, 2008; Lai, 2017; Ozer\&Tinaztepe, 2014). In Africa, studies on the effect of strategic direction have shown a positive influence on firm performance in the manufacturing, small sized medium enterprises and government sectors (Nganga, 2013; Onu, 2018; Tinarwo, 2016). Abimbola (2017) recommended that future studies may consider the inclusion of other leadership styles and its implementations in many developing countries. Locally, Ogechi and Nyamu (2016) found that strategic direction influenced firm performance in Small and Medium Enterprises in Kenya while Nthini (2013) discovered that strategic direction played a pivotal role in contributing towards performance of commercial and financial state corporations in Kenya. The respondents concurred with the fact that their institutions recorded a high net profit margin/ return on sales due to strategic management practices. The study was limited to commercial and financial state corporations hence a research gap. Nganga (2013) did a study and established a high linear relationship between performance of manufacturing firm and strategic direction and found out that firms which had leveraged on strategic direction were able to withstand the economic challenges affecting the industry and align themselves to attain competitive advantage. The study focused on manufacturing industry and leaving a gap since the manufacturing industry is broad and with many sectors. The recommendations from previous studies highlight the need to further explore the area of strategic 
direction and firm performance. Nonetheless, none of the studies that the researcher came across focused on vehicle assembly industry in Nairobi City County, Kenya and how strategic direction affects their performance. Therefore, this study sought to investigate the effect of strategic direction on performance of Motor Vehicle Assembly Firms in Nairobi City County, Kenya.

\section{Literature Review}

\subsection{Upper Echelon Theory}

This theory was advanced by Hambrick and Mason in 1984 and it argues that the personal features and attributes of a leader do reflect the type of decisions that they make in an organization. The theory is premised on the fact that the outcomes in an organizational context are directly aligned with the expertise, experience and the level of knowledge of the strategic leader in the business entity. According to Hambrick and Mason (1984), a business entity is s true reflection of the leaders with strategic mindsets in the same organization.

The theory provides an understanding of leaders with strategic traits and how this influences the ability of the firm to perform (Le-Breton-Miller \& Miller, 2018). Literature indicates that seeking to establish a link between strategic direction and the ability of the firm to perform is important for survival of any organization (Lee, Sun \& Moon, 2018). Under this theory, the key variables that can be correlated with performance of an entity include the level and background of education, the age categories, the years of experience and this provides a bio data for a strategic leader who is likely to enhance performance of the entity (Wilson \& Mooney, 2017).

Prior to the rise of strategic direction in an organization, there were no new theories that were being developed on leadership within the period of late 1970s and early 1980s. Within this period, there was no sufficient evidence to support the role played by leadership on the ability of an entity to perform (Crossland, Georgakakis, Hiller, Holcomb \&Klimoski, 2016). However, there was a paradigm shift in the field of leadership in mid 1980s with more emphasis at that time being registered on strategic direction and its role on performance of the firm. Much of the contribution to the field of strategic direction at this time was due to this theory of the upper echelon. The theory brought about a clear comprehension of strategic direction in an organization (Seaton, 2018).

Further research on this theory has confirmed that at times, the top managers play an important role as far as organizational outcomes are concerned. The emphasis of the theory is on the interaction between the management, the processes in the firm and the associated outcomes (Nacamulli, Sheldon \& Della-Torre, 2017). The theory assumes that key senior individuals in the firm are better placed to significantly impact on the organization related outcomes as informed by the level of their experience, expertise and knowledge base. The theory argues that emerging issued should be dealt with by senior staff since they have unique attributes and features that predict their strategic choices in the firm (Ohlsson\& Larsson, 2017).The theory was used to provide anchorage to the independent and dependent variables in this study.

\subsection{Strategic Direction and Firm Performance}

Strategic direction is very important in an organizational setting as it relates with the day to day choices of how well the operations of the firm are to be managed. It entails orienting the company's overall purpose considering the vision, or the bigger picture of the firm and how they support performance. Ernst and Young (2008) did a study in Ireland on the extent to which companies that adopted strategic direction achieved better performance. The adopted design was cross sectional survey and numerical as well as narrative information was sought. The views for analysis were sought from staff in the managerial as well as those not in managerial categories. The study concluded that strategic direction notably impacts the organizational. Majority of the activities linked with strategic direction of the entity were overseen by the middle as well as top managers of the entity. The study also showed that the lower level staffs were less involved in setting the strategic direction and formulation of the organization but largely ensured that the strategies formulated have been put into practice. It also found out that there was a need to involve all the staffs in setting out the strategic direction of the organization through training for effective strategic direction formulation. 
Waiganjo and Njeru (2017) conducted a study on strategic direction and its interaction with performance using evidence from government agencies operating in the tourism sector in Kenyan context. The adopted design was cross sectional and the gathered data was both qualitative as well as quantitative attributes. A total of 420 respondents were sampled and covered by the study and the response rate stood at $78 \%$. It was shown that strategic direction and firm performance are significantly linked with each other. It was also shown that there was less involvement of staff at the lower level in formulation of strategies, but rather, at the implementation phase. However, this study focused on government agencies that operate in the tourism sector and not in the motor vehicle assembly sector hence creating a contextual gap.

Nthini (2013) did a study on commercial and financial institutions and found out that strategic direction correlated highly with financial metrics such as customer satisfaction, return on investment, net profit margin and low annual employee turnover. A study conducted focusing on technical training colleges in Meru County by Muthaa and Muathe (2018) largely aimed at determining how strategic direction influences firm performance. The adopted design was descriptive cross sectional survey and questionnaires played a role in gathering of information. The analysis documented a significant interaction between strategic direction and performance of an institution. The recommendation raised by the study was the need to align the various priorities at an institutional level to the overall strategic directional at the organizational level. The limitation from this study is that it focused on technical training institutions and not motor vehicle industry hence a contextual gap.

Munyao, Chiroma and Ongeti (2020) conducted a study to link strategic direction and performance with reference to Africa Inland Church in Kenya. To gather information, the questionnaires were used. Both open as well as close ended items were included on the questionnaire. A positive and significant link was noted between strategic direction and ability of the institution to perform. This study was however conducted in a church $\mathrm{h}$ setting and not with the motor vehicle industry which creates a contextual gap. Kitonga, Bichanga and Muema (2016) focused on non-governmental organizations (NGOs) with operations in Nairobi to bring out the interaction between strategic direction and their ability to perform. A total of 328 firms were covered and the adopted design was mixed methods. It was shown that strategic direction and firm performance are positively and significantly linked with each other. However, the study focused on NGOs and not specifically on motor vehicle assembly firms.

\subsection{Conceptual Framework}

The hypothesized relationship between the independent and dependent variables adopted in this study is presented in the figure below.

Independent Variable Dependent Variable

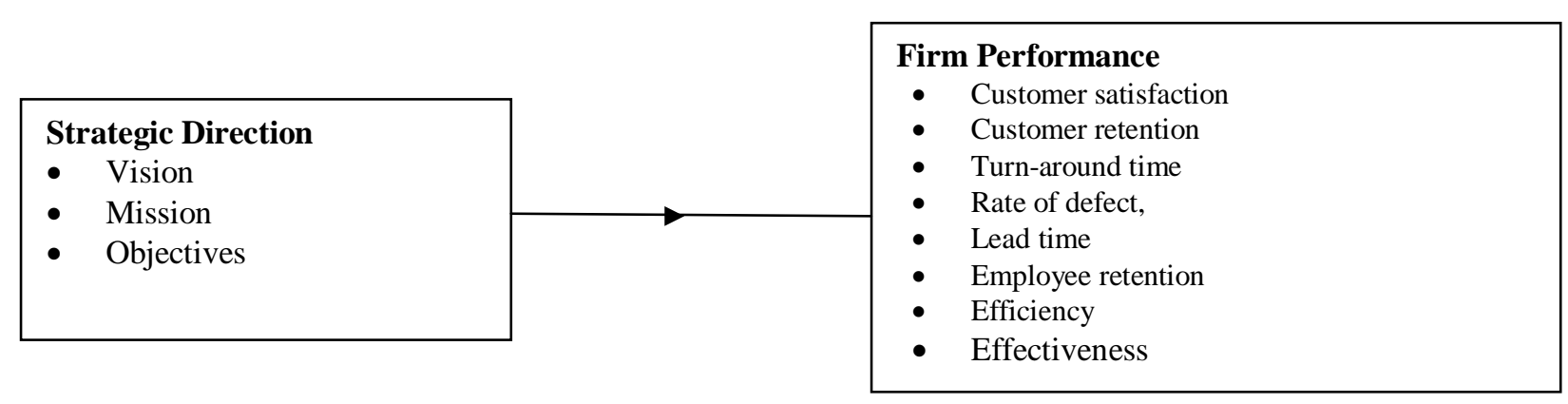

Figure1. Conceptual Framework

Source: Author (2020)

Drawing from this conceptual framework, the null and alternative research hypotheses for this study were;

$\mathbf{H}_{\mathbf{0}}$ : Strategic direction has no statistically significant effect on performance in Motor Vehicle Assembly Firms in Nairobi City County, Kenya

$\mathbf{H}_{\mathbf{1}}$ : Strategic direction has no statistically significant effect on performance in Motor Vehicle Assembly Firms in Nairobi City County, Kenya 


\section{RESEARCH METHODOLOGY}

The adopted design in this study was descriptive survey. Sekeran (2011) argue that any sound design of the study should have a well stated purpose with clarity of the objectives. Most of the studies focusing on qualitative and quantitative collection of data are mostly supported by descriptive design. The advantage of this research design is that it enables the researcher to determinethe association between the variables at a particulartime (Mugenda\&Mugenda, 2008). The existing body of empirical literature is replete with studies whose research strategy has been informed bydescriptive research design (Mbai, Kinyua\&Muhoho,2018; Kobia\&Kinyua, 2018; Kimaru\&Kinyua, 2018; Gatuyu\& Kinyua, 2020; Ontita\&Kinyua, 2020).

The study targeted 314 employees drawn from motor vehicle assemblers located in Nairobi County. The firms included Isuzu East Africa, DT Dobie, Cooper Motors Corporation, Simba Corporation and Mobius Motors (KMIA, 2016). Respondents were persons in charge of strategy, head of divisions and middle managers and lower level managers as shown in Table 1.

Table1. Target Population

\begin{tabular}{|l|l|}
\hline Firms & Target Population \\
\hline Isuzu East Africa & 75 \\
\hline DT Dobie & 70 \\
\hline Cooper Motors Corporation & 60 \\
\hline Simba Corporation & 55 \\
\hline Mobius Motors & 54 \\
\hline Total & $\mathbf{3 1 4}$ \\
\hline
\end{tabular}

Source: HR Departments of respective firms (2020)

The researcher made use stratified random sampling technique in selecting a representative sample. Kothari (2004) suggests that stratified random sampling entails sub-dividing the target population into various homogenous strata and then taking a simple random sample within each stratum. According to Cooper and Schindler (2006), a randomly chosen sample of about $10 \%$ of a population is fairly representative of the population being studied. Similarly, Mugenda and Mugenda (2003) proposed that a sample of not less than $10 \%$ of the target population can be sufficient with Kothari (2004) suggesting that such a sample should have a minimum of 30 subjects. This study sampled $50 \%$ of the population of employees of the vehicle assembly firms in Nairobi. Therefore, a sample of 157 employees was selected using 0.5 as the sampling ratio/factor. This sample was proportionately distributed across all the five strata of firms as indicated in Table 2.

Table2. Distribution of Sample Size

\begin{tabular}{|l|l|l|l|}
\hline Firms & Target Population & Sampling Ratio & Sample Size \\
\hline Isuzu East Africa & 75 & .5 & 38 \\
\hline DT Dobie & 70 & .5 & 35 \\
\hline Cooper Motors Corporation & 60 & .5 & 30 \\
\hline Simba Corporation & 55 & .5 & 27 \\
\hline Mobius Motors & 54 & .5 & 27 \\
\hline Total & $\mathbf{3 1 4}$ & & $\mathbf{1 5 7}$ \\
\hline
\end{tabular}

Source: Author (2020)

This study used primary data which was collected through semi-structured questionnaire. Kothari (2004) argues that questionnaires are good instruments for reaching respondents who are not easily approachable and is free from bias of the interviewer. The questionnaire contained Likert scale. According to Kumar (2011), Likert scales are psychometric scales that measure importance based on attitude towards an issue. Questionnaire was administered to respondents through drop and pick and online method via the email. There were three basis areas that were covered on the questionnaire which include the general information, the information relating with strategic direction and lastly information on firm performance. An introduction letter was used to request support of the exercise by the management. The questionnaire was largely made of close ended questions hence it was structured in nature. The essence of this was to ease the process of analysis of the results. It also allowed respondents an ample time to fill in the questionnaire without getting bored. The items on the questionnaire were kept as short and concise as possible so it does not become complicated for the respondents to fill in the questionnaire. 
The instruments of the study were piloted using respondents from 11 respondents purposively selected from the motor vehicle assemblers. The respondents who took part in the piloting of the instruments were completely excluded from the actual study. This was done so as to avoid possible biasness to the findings sought by the study. A pilot study is usually conducted prior to the actual research and its essence is to determine reliability and validity of the instruments. Mugenda and Mugenda (2003) refer to a pilot study as a min-study. The rationale for conducting a pilot study includes the need to identify probable challenges and issues to be encountered with the tools prior to the actual field work. This study adopted an internal measure of consistency called Cronbach Alpha coefficients to determine reliability of the instrument. In this regard, the instrument from the pilot study was coded into SPSS tool and the Cronbach Alpha coefficients were obtained for every variable. According to Sekaran (2011), the values of Cronbach Alpha coefficients of over 0.7 show that the instrument of the study are reliable. The study computed the values of Cronbach Alpha coefficients to determine reliability of the instruments. The results are as indicated in Table 3.

Table3. Reliability Test

\begin{tabular}{|l|l|l|}
\hline Study Variable & Cronbach's Alpha & Decision \\
\hline Strategic Direction & 0.889 & Reliable \\
\hline Firm Performance & 0.751 & Reliable \\
\hline
\end{tabular}

Source: Field Data (2020)

The researcher obtained a letter of introduction from St. Paul's University which stated the purpose of the study as being for academics. Thereafter, the researcher wrote to the management of the motor vehicle assembly firm, informing them of the study. A research permit from NACOSTI was sought which authorized the researcher to go to the field and collect data from the respondents. The researcher administered the questionnaires to respondents through email address. Each questionnaire was accompanied with a letter of introduction from the University top provide assurance to respondents as they filled in the questionnaire. Phone calls were also used to reinforce the response rate. Data obtained from the field was cleaned for errors, edited, coded, classified and tabulated.

Descriptive statistics and inferential statistics were used to analyze data. They include frequency distribution, measures of central tendency (mean) and measures of variation (standard deviation) and generalizations. The inferential statistics were undertaken using regression analysis. The regression model which was used in the study is shown below:

$\boldsymbol{Y}=\boldsymbol{\beta}_{0}+\boldsymbol{\beta}_{1} \boldsymbol{X}_{1}+\varepsilon$

Where; Y= Organizational performance

$\beta_{i}=$ Coefficients of regression

$\mathrm{X}_{1}=$ Strategic direction

$\varepsilon=$ error term

The coefficient of determination ( $\mathrm{R}$ Square) was examined to indicate the variance in percentage which was explained by the indicators of an individual independent variable (cumulatively) on the dependent variable. The Analysis of Variance (ANOVA) was used to test whether the overall model was statistically significant. The $p$ values in respect to individual variables generated in the regression analysis were used to determine whether the model was reliable. In this context, p-values less than 0.05 tested at $95 \%$ confidence level implied that the model was a good fit for data, hence reliable in its prediction.

\section{DISCUSSION OF FINDINGS}

The researcher administered 157 through drop and pick and online methods to the respondents of the study. From these questionnaires, 104 of them were dully filled by the respondents and emailed back to the researcher. This was equivalent to a response rate of $66 \%$ as shown in Figure 4.1. The response was in line with Mugenda and Mugenda who provide that a response rate of above $60 \%$ is deemed to be good for presentation of the findings. However, an ideal response rate is one ranging from above $70 \%$ and thus the response rate in this study was relatively low. The key reasons that may have attributed to this relatively low response rate in this study could be the Covid-19 virus that had created a health crisis around the world. 
Analysis of the Effect of Strategic Direction on Performance of Motor Vehicle Assembly Firms in Nairobi City County, Kenya

\subsection{Descriptive Statistics for Strategic Direction}

Table4. Descriptive Statistics on Strategic Direction

\begin{tabular}{|c|c|c|c|c|c|}
\hline & n & Min & Max & Mean & Std. Dev \\
\hline Your firm has a working strategic plan & 33 & 2.00 & 5.00 & 3.75 & .708 \\
\hline $\begin{array}{l}\text { There is deliberate review of strategic plan after every five } \\
\text { year cycle }\end{array}$ & 33 & 2.00 & 5.00 & 3.72 & 1.039 \\
\hline Resources are aligned to the strategic objectives of the firm & 33 & 2.00 & 5.00 & 3.63 & 1.140 \\
\hline $\begin{array}{l}\text { The organization relies on strategic direction to make } \\
\text { decisions }\end{array}$ & 33 & 2.00 & 5.00 & 3.87 & .960 \\
\hline Aggregate Score for Strategic Direction & 33 & & & 3.74 & 0.962 \\
\hline
\end{tabular}

Source: Field Data (2020)

The respondents agreed $(\mathrm{M}=3.74, \mathrm{SD}=.962)$ that strategic leadership was highly practiced in their organizations. This result is supported by Ernst and Young (2008) who did a study in Ireland on the extent to which companies that adopted strategic direction achieved better performance. It was shown that key issues related with strategic movement and direction of the entity is overseen by the middle and the senior managers and that implementation of strategic plans is usually done by the lower staff.

The overall value of standard deviation is less than 1 . This shows that respondents had convergent opinions and views on strategic direction in their organization except on deliberate review of strategic plan after every five year cycle $(\mathrm{M}=3.7, \mathrm{SD}=1.039)$ and resources being aligned to the strategic objectives of the firm $(\mathrm{M}=3.63, \mathrm{SD}=1.140)$. The high values of standard deviation on these statements imply that respondents had mixed reactions on them as some of them agreed; others disagreed while others maybe were not sure.

\subsection{Descriptive Statistics for Firm Performance}

Table5: Descriptive Statistics for Firm Performance

\begin{tabular}{|l|l|l|l|l|l|}
\hline & $\mathbf{n}$ & Min & Max & Mean & Std. Dev \\
\hline $\begin{array}{l}\text { Strategic Leadership facilitates the speed of response to customers } \\
\text { issues }\end{array}$ & 33 & 2.00 & 5.00 & 3.58 & .992 \\
\hline $\begin{array}{l}\text { Strategic Leadership facilitates minimization of period between } \\
\text { order placement and delivery in the firm }\end{array}$ & 33 & 2.00 & 5.00 & 3.36 & 1.055 \\
\hline Strategic leadership leads to repeat customers & 33 & 2.00 & 5.00 & 3.78 & .927 \\
\hline Strategic leadership supports realization of non-defective output & 33 & 2.00 & 5.00 & 3.45 & .791 \\
\hline Strategic leadership supports realization of low employee turnover & 33 & 2.00 & 5.00 & 3.90 & 1.011 \\
\hline Aggregate Score for Firm Performance & 33 & & & $\mathbf{3 . 6 1}$ & $\mathbf{0 . 9 5 5}$ \\
\hline
\end{tabular}

Source: Field Data (2020)

The results indicate an overall mean score $(\mathrm{M}=3.61, \mathrm{SD}=0.955)$; this means that majority of the respondents agreed on the statements provided under firm performance. The overall standard deviation is 0.955 ; which is less than 1 . This means that respondents shared same opinions and views on performance of their organization expect on strategic leadership facilitates minimization of period between order placement and delivery in the firm $(\mathrm{M}=3.36, \mathrm{SD}=1.055)$ and strategic leadership supports realization of low employee turnover $(\mathrm{M}=3.90 \mathrm{SD}=1.011)$ where respondents had mixed reactions. These views are supported by Nthini (2013) who did a study on commercial and financial institutions and found out that strategic direction correlated highly with financial metrics such as customer satisfaction, return on investment, net profit margin and low annual employee turnover.

\subsection{Correlation Analysis}

Correlation analysis was conducted to establish the relationship between strategic direction and firm performance as indicated in Table 3.

Table6. Correlation Matrix

\begin{tabular}{|l|l|l|}
\hline & Firm Performance & Strategic Direction \\
\hline Firm Performance & 1 & \\
\hline Strategic Direction & 623 & 1 \\
\hline
\end{tabular}

Source: Field Data (2020) 
Table6 indicate that strategic direction $(\mathrm{r}=0.623)$ has a strong and positive relationship with firm performance. This result is supported by Nthini (2013) who did a study on commercial and financial institutions and found out that strategic direction correlated highly with metrics such as customer satisfaction, return on investment, net profit margin and low annual employee turnover.

\subsection{Test of Hypothesis}

A simple regression analysis was conducted to establish the effect of strategic direction onfirm performance .Tables 7shows the summary of the regression equation.

Table7. Model Summary

\begin{tabular}{|l|l|l|l|l|}
\hline Model & R & R Square & Adjusted R Square & Std. Error of the Estimate \\
\hline 1 & $.875^{\text {a }}$ & .766 & .732 & 1.60515 \\
\hline
\end{tabular}

a. Predictors: (Constant), Strategic Direction

Source: Field Data (2020)

The results in Table 7 indicate that $\mathrm{R}$ is 0.875 ; which is interpreted to imply that strategic direction is a strong and positive correlate of firm performance. The value of $\mathrm{R}$ square is 0.766 ; this shows that the multiple regression model of the study was fit. The adjusted $\mathrm{R}$ square is 0.732 ; this deduces that $73.2 \%$ change in firm performance is explained by strategic direction in an organization. Thus, apart from strategic direction, there are other factors with an influence to firm performance which explain $26.8 \%$ of performance at the firm level. The results of ANOVA for the overall model of the study are as indicated in Table 8.

Table8. Overall ANOVA Results

\begin{tabular}{|l|l|l|l|l|l|}
\hline & Sum of Squares & df & Mean Square & F & Sig. \\
\hline Regression & 235.737 & 4 & 58.934 & 22.874 & $.000 \mathrm{~b}$ \\
\hline Residual & 72.142 & 28 & 2.577 & & \\
\hline Total & 307.879 & 32 & & & \\
\hline
\end{tabular}

a. Dependent Variable: Firm Performance

b. Predictors: (Constant), Strategic Direction

Source: Field Data (2020)

As indicated in Table 8, the value of $\mathrm{F}$ calculated is 22.874; this shows that the overall regression model used to test the relationship between strategic direction and firm performance was significant. The p-value was less than 0.05; which imply that at least one of the independent variables of strategic direction has significant influence on firm performance. This result is supported by Nthini (2013) who did a study on commercial and financial institutions and found out that strategic direction correlated highly with financial metrics such as customer satisfaction, return on investment, net profit margin and low annual employee turnover. The results of the regression coefficients and the p-values which show significance of the individual variables are summarized in Table 9.

Table9. Overall Beta Coefficients and Significance

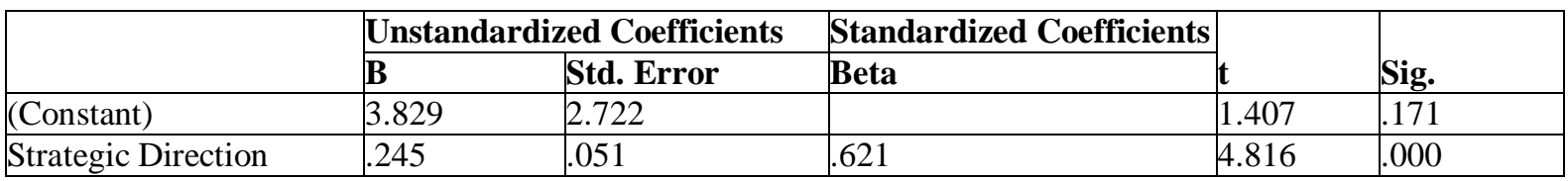

a. Dependent Variable: Firm Performance

Source: Field Data (2020)

Based on the results in Table 9, the following equation is derived:

\section{Performance $=3.829+.245$ Strategic Direction}

Therefore, at $5 \%$ level of significance, the study noted that strategic direction had a positive beta coefficient $(\beta=.245)$ with a $\mathrm{p}$-value $(\mathrm{p}=0.000)$ which is less than 0.05 . This infers that strategic direction has a positive and significant effect on firm performance. The result is empirically supported by Ernst and Young (2008) who did a study in Ireland on the extent to which companies that adopted 
strategic direction achieved better performance and noted that strategic direction notably impacts the organizational. Similarly, Nthini (2013) did a study on commercial and financial institutions and found out that strategic direction correlated highly with metrics such as customer satisfaction, return on investment, net profit margin and low annual employee turnover.

\section{CONCLUSION AND RECOMMENDATIONS}

The study's objective sought to assess the effect of strategic direction on performance of motor vehicle assembly firms in Nairobi City County, Kenya. Regression analysis and descriptive statistics like means and standard deviations were used to achieve this objective. From the regression results, strategic direction had a positive beta coefficient. Thus, the study concludes that strategic direction has a positive and significant effect on performance of motor vehicle assembly firms in Nairobi City County. From the results of descriptive statistics, the study concludes that strategic direction is practiced in the motor vehicle assembly industry in Nairobi City County. Thus, the study recommends that the board of directors and chief executive officer's and managers involved in strategy formulation of motor vehicle assembly firms in Nairobi City County should adopt strategic direction practices by constantly renewing the mission and vision statements of their organizations.

\subsection{Recommendations for Further Studies}

The present study focused on the motor vehicle assembly firms inNairobi City County. Thus, a recommendation is provided for future studies to cover other sectors like manufacturing firms and other service oriented firms. The study focused on strategic direction and firm performance. Specifically, the study covered three dimensions of strategic direction which were vision, mission and objectives. However, there are still other measures of strategic direction that future studies should focus on. Additionally, further studies can also be conducted with a focus on other dependent variables like financial performance, competitive advantage or operational performance rather than just the general firm performance.

\section{REFERENCES}

[1] Abimbola, O., S. (2017). The Influence Of Leadership Styles On Employees' Performance: A Study Of Selected Private Universities In Ogun State, Nigeria. Global Journal of Commerce \& Management Perspective, 6(2), 5-13. https://doi.org/10.24105/gjcmp.6.2.1702

[2] Agbim, K. C. (2018). Effect of Ethical Leadership on Corporate Governance, Performance and Social Responsibility: A Study of Selected Deposit Money Banks on Benue State, Nigeria. 17.

[3] Ahmed, M., \&Shafiq, S. (2014). The Impact of Organizational Culture on Organizational Performance: A Case Study of Telecom Sector. 11.

[4] Ali, H. S. H., Said, R. M., Abdullah, A., \&Daud, Z. M. (n.d.). The Impact Of Organizational Culture On Corporate Financial Performance: A Review. 13.

[5] Al-Sharafat, A. (2017). The Impact of Human Capital Development on the Financial Performance of Agricultural Enterprises: Application on Broiler Industry. 8(3), 8.

[6] Amisano, D., \& Anthony, P. (2017).Relationship between ethical leadership and sustainability in small businesses.Journal of Leadership, Accountability and Ethics 14(3), 76-90

[7] Appannaiah, H. R., P.N. Reddy, \& B. Rose Kavitha.(2009). Organisational Behaviour. Retrieved from http://ebookcentral.proquest.com/lib/stpaulslimuru-ebooks/detail.action?docID=3011144

[8] Barare, N. B. (2018). Ethical Leadership and Performance Of State Corporations In Kenya: A Case Study Of Kenya Revenue Authority. 95.

[9] Bernstein, R., Buse, K., \&Bilimoria, D. (2016).Revisiting agency and stewardship theories: Perspectives from nonprofit board chairs and CEOs. Nonprofit Management and Leadership, 26(4), 489-498.

[10] Chen, Y. M., Liu, H. H., Yang, Y. K., \& Chen, W. H. (2016). CEO succession in family firms: Stewardship perspective in the pre-succession context. Journal of Business Research, 69(11), 5111-5116.

[11] Black, A., \& McLennan, T. (2016). The last frontier: Prospects and policies for the automotive industry in Africa. International Journal of Automotive Technology and Management, 16(2), 193. https://doi.org /10.1504/IJATM.2016.079232

[12] Butts, J. B. (2012).Ethics in Organizations and Leadership. 34.

[13] Chigozie, M. P. (2018). Effect of Human Capital Development in Organizational Performance in Manufacturing Industries in South-East Nigeria.7 (3), 18. 
[14] Choi, D. W., Chatfield, H. K., \& Chatfield, R. E. (2018). Agency or stewardship? International Journal of Contemporary Hospitality Management.

[15] Crossland, C., Georgakakis, D., Hiller, N. J., Holcomb, T. R., \&Klimoski, R. J. (2016). Interfaces of Strategic Leaders: Developing a Future Research Agenda. In Academy of Management Proceedings (Vol. 2016, No. 1, p. 11350). Briarcliff Manor, NY 10510: Academy of Management.

[16] Davies, B., \& Davies, B. J. (2010).The Nature and Dimensions of Strategic Leadership. 18.

[17] Domínguez-Escrig, E., Mallén-Broch, F. F., Lapiedra-Alcamí, R., \&Chiva-Gómez, R. (2019). The influence of leaders' stewardship behavior on innovation success: the mediating effect of radical innovation. Journal of Business Ethics, 159(3), 849-862.

[18] DuBrin, A. J. (2012). Leadership: Research Findings, Practice, and Skills. Cengage Learning.

[19] Eigbiremolen, G. O., \&Anaduaka, U. S. (2014). Human Capital Development and Economic Growth: The Nigeria Experience. International Journal of Academic Research in Business and Social Sciences, 4(4), 11.

[20] Erdogan, B., Talya Bauer, Carpenter, M. A., \& Jeremy Short.(2012). Developing Mission, Vision, and Values. 53.

[21] Farkas, G. (2016). Agent-principal problem, stewardship theory and behavioural agency model in the explanation of family business performance.

[22] Gachugu, E. M., Awino, Z. B., Iraki, X. N., \&Machuki, V. (2019). Top Management Team Diversity and Organizational Performance: An Empirical Investigation of Strategic Leadership Influence. Journal of Strategic Management, 3(2), 15-29.

[23] Gallos, J. V., \& Heifetz, R. A. (2008). Business Leadership: A Jossey-Bass Reader. Retrieved from http://ebookcentral.proquest.com/lib/stpaulslimuru-ebooks/detail.action?docID=1666502

[24] Gatuyu, C. M. \&Kinyua, G. M. (2020).Role of Knowledge Acquisition on Firm Performance in the Context of Small and Medium Enterprises in Meru County, Kenya. Journal of World Economic Research,9(1): 27-32.

[25] Hansen, S. D. (2011). Ethical Leadership: A Multifoci Social Exchange Perspective.

[26] Hegarty, N., \&Moccia, S. (2018). Components of Ethical Leadership and Their Importance in Sustaining Organizations over the Long Term. Journal of Values-Based Leadership, 11(1). https://doi.org/10.22543 /0733.111.1199

[27] Hirschi, G., \& Jones, M. (2009). Effects of strategic leadership on business success-A cross-cultural analysis from a resource based view. 3(1), 20.

[28] Ireland, R. D., \&Hitt, M. A. (1999). Achieving and Maintaining Strategic Competitiveness in the 21st Century: The Role of Strategic Leadership. The Academy of Management Executive (1993-2005), 13(1), 43-57. Retrieved from JSTOR.

[29] Jaleha, A. A., \&Machuki, V. N. (2018). Strategic Leadership and Organizational Performance: A Critical Review of Literature. European Scientific Journal ESJ, 14(35). https://doi.org/10.19044/esj.2018.v14n3 $5 \mathrm{p} 124$

[30] KAM-Manufacturing-Deep-Dive-Report-2018.pdf. (n.d.). Retrieved from http://kam.co.ke/kam/wpcontent/uploads/2018/10/KAM-Manufacturing-Deep-Dive-Report-2018.pdf

[31] Kasera, G. K. (2017). Strategic Management and Organizational Performance: Findings from Health Institutions In Nairobi County. 130.

[32] Keay, A. (2017). Stewardship theory: is board accountability necessary?. International Journal of Law and Management.

[33] Khademfar, M. (2013).The Relationship between Ethical Leadership and Organizational Performance.4(1), 7.

[34] Kimaru, I. W. \&Kinyua, G. (2018).Relationship between Financial Resources and Performance of Credit Only Microfinance Institutions in Kenya.International Journal of Innovative Research and Advanced Studies, 5(11): 1-6.

[35] Kitonga, D. M. (2017). Strategic Leadership Practices and Organizational Performance In Not-For-Profit Organizations In Nairobi County In Kenya. 214.

[36] Kitonga, D.M., Bichanga, W. O., Muema, B. K. (2016). The role of determining strategic direction on Not-For-Profit Organizational performance in Nairobi County in Kenya. International Journal of Scientific \& Technology Research 5(5), 28-32

[37] KMIA (2016).Annual Report and financial Statements. Kenya Motor Industries Association: Nairobi, Kenya

[38] KNBS (2019).Economic Survey. Government Printers: Nairobi, Kenya. 
[39] Kobia, F. K. \&Kinyua, G. (2018).An Empirical Analysis of the Relationship between Product Development and Performance of Outlets of Bata Shoe Company in Nairobi City County, Kenya.International Journal of Innovative Research and Advanced Studies, 5(10):55-60.

[40] Lai, L. (2017, January 18). Being a Strategic Leader Is About Asking the Right Questions. Harvard Business Review. Retrieved from https://hbr.org/2017/01/being-a-strategic-leader-is-about-asking-theright-questions

[41] Le Breton-Miller, I., \& Miller, D. (2018). Looking back at and forward from:“Family governance and firm performance: Agency, stewardship, and capabilities". Family Business Review, 31(2), 229-237..

[42] Leavell, M. L. (2016). Assessing the relationship between faith maturity and stewardship among top-level christian leaders (Doctoral dissertation, Grand Canyon University).

[43] Lee, W. S., Choi, C., \& Moon, J. (2018). The upper echelon effect on restaurant franchising: the moderating role of internationalization. International Journal of Culture, Tourism and Hospitality Research.

[44] Lin, Z., Wang, H., Zhang, H., Wang, Y., \& Liu, X. (2018, July). CEO Dialectical Leadership Behavior and Its Effects On Firm Performance. In Academy of Management Proceedings (Vol. 2018, No. 1, p. 15923). Briarcliff Manor, NY 10510: Academy of Management.

[45] Lubogoyi, B., Kasekende, F., Kagaari, J., Ngoma, M., Munene, J. C., \&Bakunda, G. (2018). Stewardship behaviour and perceived goal congruence in local governments in Uganda. Leadership \& Organization Development Journal.

[46] Madison, K., Holt, D. T., Kellermanns, F. W., \&Ranft, A. L. (2016).Viewing family firm behavior and governance through the lens of agency and stewardship theories. Family Business Review, 29(1), 65-93.

[47] Manduku, D. O. (2017).The influence of ethical leadership on the financial performance of listed firms in Kenya.USIU Repository

[48] Marimuthu, M., Arokiasamy, L., \& Ismail, M. (2009). Human capital development and its impact on firm performance: evidence from developmental economics. 2, 8.

[49] Martin, J. A., \& Butler, F. C. (2017). Agent and stewardship behavior: How do they differ?. Journal of Management \& Organization, 23(5), 633-646.

[50] Mbai, W., Kinyua, G., \&Muhoho, J. (2018).Corporate Leadership and Performance of Machakos Water and Sewerage Company in Kenya. The Strategic Journal of Business \& Change Management, 5(3), 631639.

[51] Mbugua, J. W. \&Kinyua, G. M. (2020). Service Differentiation and Organization Performance: An Empirical Analysis of Deposit Taking SACCOs in Nairobi City County, Kenya. Journal of Business and Economic Development, 5(2): 64-72.

[52] Mihelic, K. (2010). Ethical Leadership.Information Systems, 14(5), 12.

[53] Mirugi, T. \&Kinyua, G. M. (2018). Analysis of the Effect of Block Ownership on Performance of Listed Commercial Banks in Nairobi County, Kenya.Strategic Journal of Business and Change Management, 5(4): $2180-2188$.

[54] Mucci, D. M., Frezatti, F., Jorissen, A., \&Bido, D. D. S. (2020). Stewardship-oriented culture and family firm performance: A study on the moderating effects in an emerging economy. BAR-Brazilian Administration Review, 17(2).

[55] Munyao, S.M., Chiroma, N. H. \&Ongeti, W. J. (2020).Effects of strategic direction on the performance of Africa Inland Church Theological Training Institutions in Kenya.International Journal of Scientific and Research Publications, 10(3), 352- 357

[56] Musonye, N., \&Nyaga, J. (2019). Leadership Practices, Employee Competence and Performance of the Betting Companies in Kenya: A Case of Sportpesa Betting Company. Journal of Human Resource \& Leadership, 3(4), 1-13.

[57] Muthaa, G. M., \&Muathe, S. M. A. (2018).Effect of strategic direction on the performance of technical training institutions in Meru County, Kenya.Proceeding of the 1st Annual International Conference held on 17th-19th April 2018, Machakos University, Kenya

[58] Muthoni, D. M..\&Kinyua G. M. (2020) Corporate Reputation and Firm Performance: An Empirical Analysis of Motor Vehicle Assemblers in Nairobi City County, Kenya. Journal of Business and Economic Development. Vol. 5, No. 2, 2020, pp. 73-81. doi: 10.11648/j.jbed.20200502.13

[59] Nacamulli, R., Sheldon, P., \& Della-Torre, E. E. (2017). Meta-Organizations and Upper Echelons: Exploring Strategic and Organizational Change in Employer Associations.

[60] Nganga, U. M. (2013). Strategic Leadership and Performance Of Manufacturing Firms In Kenya. 57. 
[61] Nthini, E. K. (2013). Effect of strategic leadership on the performance of commercial and financial state corporations in Kenya.

[62] Ogechi, R. N., \&Nyamao, O. R. (2016a). The Effect Of Strategic Leadership On The Performance Of Small And Medium Enterprises In Kenya.

[63] Ogechi, R. N., \&Nyamao, O. R. (2016b). The Effect of Strategic Leadership On The Performance Of Small And Medium Enterprises In Kenya.

[64] Ogolla, N. O. (2013). Operations Strategy and Performance among Motor Vehicle Assemblers in Kenya. Master of Business Administration: University of Nairobi, Kenya.

[65] Ohlsson, A., \& Larsson, G. (2017). Emotions in strategic leadership: A Literature review and theoretical modelling for future research directions. International Journal of Organization Theory and Behavior, 20(03), 311-340.

[66] Ontita, J. \&Kinyua, G. M. (2020). Role of Stakeholder Management on Firm Performance: An Empirical Analysis of Commercial Banks in Nairobi City County, Kenya. Journal of Business and Economic Development, 5(1): 26-35.

[67] Onu. (2018). Strategic Leadership and Organizational Performance in Nigeria: An Empirical Investigation.

[68] OrganisationalBehaviour. (2009). Retrieved from http://ebookcentral.proquest.com/lib/stpaulslimuruebooks/detail.action?docID=3011144

[69] Ouma, C. N. (2017). The effect of ethical leadership on employee commitment among managers in the transport sector parastatals in Kenya. 310.

[70] Ozer, F., \&Tinaztepe, C. (2014). Effect of Strategic Leadership Styles on Firm Performance: A Study in a Turkish SME. Procedia - Social and Behavioral Sciences, 150, 778-784. https://doi.org/10.1016/ j.sbspro.2014.09.059

[71] Pillay, K. (2015). Europe, Middle East \& Africa Automotive Leader Deloitte. 48.

[72] Pm, K. (2019). Corporate culture and organizational performance: A case of Mayfair casino, Nairobi city county, Kenya. 10.

[73] Rao, P. S. (2010). Organisational Behaviour. Retrieved from http://ebookcentral.proquest.com/lib/stpa ulslimuru-ebooks/detail.action?docID $=618259$

[74] Richard, P. J., Devinney, T. M., Yip, G. S., \& Johnson, G. (2009). Measuring Organizational Performance: Towards Methodological Best Practice. Journal of Management, 35(3), 718-804. https://doi.org/10.1177/0 149206308330560

[75] Saha, R., Cerchione, S. R., Singh, R., \&Dahiya, R. (2019). Effect of ethical leadership and corporate social responsibility on firm performance: A systematic review. Corporate Social Responsibility and Environmental Management 27(2), 409-429

[76] Schiller, D. T. (2018).Africa Automotive Leader Deloitte Africa. 52.

[77] Seaton, L. J. (2018). The relationship of confucian dynamism and the strategic leader: An Upper Echelon Theory Perspective. International Journal of the Academic Business World, 12(1), 113-119.

[78] Sekaran, U., \& Bougie, R. (2011). Research Methods for Business: A Skill Building Approach (5th ed.). Delhi: Aggarwal printing press.

[79] Smith, P., Farmer, M., Yellowley, W., \& Smith, P. (2012).Organizational Behavior. Retrieved from http://ebookcentral.proquest.com/lib/stpaulslimuru-ebooks/detail.action?docID=967187

[80] Subramanian, S. (2018). Stewardship Theory of Corporate Governance and Value System: The Case of a Family-owned Business Group in India. Indian Journal of Corporate Governance, 11(1), 88-102.

[81] Tinarwo, R. (2016). An investigation into the challenges faced by Small to Medium Enterprises in Zimbabwe: A case of Gazaland Market. https://doi.org/10.9790/487X-180902148153

[82] Wahjudi, D., Singgih, M., \&Baihaqi, I. (2013). The Impact of Organizational Culture on Firm Performance: An Empirical Research on Indonesian Manufacturing Firms.

[83] Waiganjo, E. W., \&Njeru, A. W. (2017). Influence of strategic direction on organizational performance in tourism government agencies in Kenya. International Journal of Business and Commerce 6(4), 18-36

[84] Wilson, B., \& Mooney, K. (2017). Exploring Effective Accounting Ethics Cpe from An Upper Echelon Theory Perspective. QRBD, 21.

[85] Yesil, S., \& Kaya, A. (2013). The Effect of Organizational Culture on Firm Financial Performance: Evidence from a Developing Country. Procedia - Social and Behavioral Sciences, 81, 428-437. https://doi.org/10.1016/j.sbspro.2013.06.455 
[86] Yuhyung, S,. Sung, S, Y. M, Choi, J. N., \& Kim, M. S. (2014). Top management ethical leadership and firm performance: mediating role of ethical and procedural justice climate. Journal of Business Ethics 129(4), 43-57

\section{AUTHOR'S BIOGRAPHY}

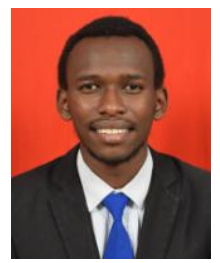

SHEM MAINA KUNGU, is a Postgraduate student at St. Paul's University Kenya. His research interests include strategic management,change management and innovation management.

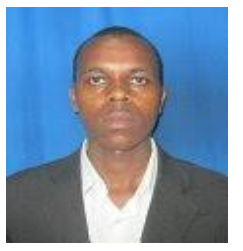

DR. JULIUS KAHUTHIA MWANGI, A lecturer and researcher in areas of Strategic Management, Knowledge Management and Strategic Change Management as well as Management courses.

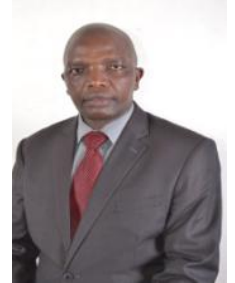

DR. GODFREY MUIGAI KINYUA, Dr. Godfrey M. Kinyua is a Lecturer in the Department of Business Administration, School of Business of Kenyatta University. He holds a Doctor of Philosophy in Business Administration from Kenyatta University, Master of Business Administration from the University of Nairobi and Bachelor of Education from Egerton University.

Citation: Shem Maina Kungu, et.al. "Analysis of the Effect of Strategic Direction on Performance of Motor Vehicle Assembly Firms in Nairobi City County, Kenya" International Journal of Managerial Studies and Research (IJMSR), vol 8, no. 8, 2020, pp. 82-94. doi: https://doi.org/10.20431/2349-0349.0808009.

Copyright: () 2020 Authors. This is an open-access article distributed under the terms of the Creative Commons Attribution License, which permits unrestricted use, distribution, and reproduction in any medium, provided the original author and source are credited. 